\title{
Teachers Work Motivation in Improving the Quality of Learning
}

\author{
Basri \\ Study Program of Educational Management \\ Postgraduate Program \\ Universitas Negeri Medan \\ Medan, North Sumatera, Indonesia \\ email: basri6609@gmail.com
}

\author{
Saut Purba \\ Postgraduate Program \\ Universitas Negeri Medan \\ Medan, North Sumatera, Indonesia
}

\author{
Rosmala Dewi \\ Postgraduate Program \\ Universitas Negeri Medan \\ Medan, North Sumatera, Indonesia
}

\begin{abstract}
Teachers motivation in working is very necessary in achieving maximum school goals and giving high loyalty to their duties and responsibilities. This study aims to find the form of work motivation of teachers in improving the quality of learning in Senior High School 1 Sigli in Pidie District. The method used in this study is a naturalistic qualitative method. Data collection techniques are carried out through interviews, observation, and documentation. Data analysis techniques used are data reduction, data presentation, and conclusion drawing. The results showed that: Motivation done by the teacher in carrying out his duties and responsibilities by: explaining the benefits and objectives of the material taught to students, teaching using various learning methods or strategies, provide opportunities for students to achieve success, and giving awards or praise to students who perform tasks and perform well. The factors that influence teachers work motivation are two types, namely intrinsic motivation and extrinsic motivation. Most teachers have sufficient professional skills in carrying out their duties and responsibilities properly.
\end{abstract}

Keywords-Teachers, work, motivation, quality, learning.

\section{INTRODUCTION}

The quality of human resources and educational development ranks first, which must be addressed by the Government. This means that the factors of Human Resources (HR) and education still have problems and must be addressed immediately. Improving the quality of better education by preparing competent Human Resources in their respective fields in order to make changes and adjustments to the advancement of science and technology.

The foundation for improving the quality of education can be demonstrated by the quality of performance produced by teachers. Teacher performance standards need to be formulated to be used as a reference in making comparisons of what is achieved with what is expected, or the quality of performance is a form of behavior or activities carried out and in accordance with expectations and needs or goals to be achieved effectively and efficiently.
Performance refers to dimensions related to work behavior, work results, as well as the personal nature of someone who is oriented to effectiveness and efficiency to achieve a goal both individuals and organizations. Individuals in the organization are important aspects that determine the effectiveness of an organization. For organizations, work done by individuals is an investment [1], because they have to give their time, effort, and effort [2]. Therefore, it is necessary for the school leader's wisdom to create a situation that creates motivation for the teacher to act and behave as desired.

This is based on the fact that performance is always reported as a significant indicator of organizational performance [3]. Over the past 10 or 15 years, researchers have made progress in clarifying and expanding the concept of performance. Performance does not have to be seen directly into someone's behavior. This consists of mental results such as an answer or decision result. But performance needs to be part of individual control. Performance is a concept developed based on various perspectives, such as type, dimension, influence, and performance parameters [4].

The demand for the development of human resource capabilities is how each element of leadership can develop and mobilize others, both subordinates and other related parties, so that the desired common goals are achieved, consciously they are willing to behave to work so that the output or quality of learning is desired. In other words, the problem of teacher's work motivation is one aspect that must receive special attention from each school institution in improving optimal educational productivity in accordance with the goals of a school. School leaders in this case play an important role in creating work motivation and excitement as well as supporting facilities for teachers to carry out their duties and responsibilities.

One of the efforts to increase the motivation of the teachers to work is through procedural incentives, both financial and non-financial. Besides that, it is also necessary to pay attention to several other elements such as work safety, pleasant work environment in school, provision of salaries and 
other benefits and the availability of various facilities that can motivate the work of teachers in carrying out their duties. If the leadership of each school has paid close attention to the various needs of the teachers, it will be very easy to increase the motivation, productivity and excitement of the teachers' work in teaching. That motivation is always related to three things, namely someone who works hard, maintains his profession and directs his work to achieve organizational goals [5].

Work motivation in various forms in the school environment will increase the excitement of teachers in carrying out their duties and responsibilities. The fact that all this time is still low in educational productivity possessed by each school because of the lack of motivation carried out by the leadership so that it has an impact on student learning achievement. Observation results in the field found that in the learning process that had taken place at Senior High School 1 Sigli was still not optimal. There are many things that influence it such as the lack of work motivation of some teachers in terms of self-development, rarely writing articles, and the motivation of teachers in conducting classroom action research. In addition, there is also found leadership that is not active from a teacher when in class, this means when a teacher is in the classroom the atmosphere of the class seems boring and many students are not excited when receiving the lesson.

Based on the above problems, the purpose of this study is to find the form of work motivation of teachers in carrying out their duties and responsibilities in improving the quality of learning; and factors that influence the work motivation of teachers at Senior High School 1 Sigli in Pidie District

\section{METHOD}

The method used in this study is a naturalistic qualitative method. Qualitative research method is a method used to examine the condition of natural objects, where researchers are as a key instrument source, data collection techniques are carried out in triangulation (combined), data analysis and are inductive and the results of qualitative research emphasize meaning rather than generalization [6].

The location of the research at Senior High School 1 Sigli in Pidie District. Subjects in this study were teachers totaling 88 people consisting of 21 male teachers and 67 female teachers. Sources of data in this study are key informan consisting of teachers, principal, and relevant documents according to the research focus.

Data collection techniques are carried out through interviews, observation, and documentation. Data analysis techniques used are data reduction, data presentation, and conclusion drawing [7]. Trustworthiness is based on four criteria: credibility, transferability, dependability, and confirmability [8].

\section{FINDING AND DISCUSSION}

The results show that learning requires constant motivation to remain high from students. The efforts made by the teacher are explaining the benefits and objectives of the material taught to students, so that students feel truly felt they need to learn. Then the step taken is that the teacher chooses the material or lesson material needed by the student and is determined in the curriculum. Something needed will attract students' interest to generate learning motivation.

Other efforts carried out by teachers are teaching using various learning methods or strategies, involving students directly in teaching and learning activities. Like biology subjects, teachers often use experimental methods that make students interested and curious about what they learn. When the researcher observes the biology teacher is conducting an experiment using a microscope. It is clear that the students are very enthusiastic to learn and the motivation to learn is quite high. The exercises and assignments given are also always checked and given a value that matches the results of his work. If there are students who do their jobs well the teacher always gives awards in the form of praise and good grades. This is one of the teachers efforts to increase students' motivation in learning.

Research findings indicate that various motivations that teachers do to carry out their duties and responsibilities in improving the quality of learning include: (a) explaining the benefits and objectives of the material taught to students, so that students feel they really need to learn. Because by knowing the purpose and benefits of the material being taught, students are motivated to learn. Motivation as a whole the power of movement in students that lead to learning activities, which ensures the continuity of learning activities, so that the desired goals by the subject of learning [9]. Furthermore (b) teaching using various learning methods or strategies, involving students directly in teaching and learning activities, (c) providing opportunities for students to achieve success by providing both structured and unstructured tasks and exercises that can increase student motivation in learning, (d) give awards or praise to students who perform tasks and perform well.

Motivation is a psychological process that finds interaction between attitudes, needs, perceptions and decisions that occur in someone. There are two factors that cause motivation to emerge, namely the factors within a person and factors outside of a person. The following will explain the findings of the study relating to the work motivation of teachers at Senior High School 1 Sigli in Pidie District based on these two factors.

\section{1) Intrinsic motivation}

First, a teacher's talents and interests require a special test, however in this study to find out the talents and interests of a teacher in terms of attitude and personality in carrying out his duties as a teacher which is always an example and imitated by students. Based on the results of interviews with principals it was found that teachers had material-oriented personalities, not their responsibilities and obligations as teachers, but there were also teachers who were sincere in carrying out their duties and obligations very well in very few numbers. Besides that the teacher is more individual or in other words accentuating each of his personalities so as to form a work team rather difficult. Even though we know that working with a team is better than working individually, the burden can be solved together and lighter. 
Second, the education background of a teacher greatly influences the ability of teachers to teach and their success in carrying out work in any form. The higher the education he attained, the more open the opportunity to be successful in various fields that he practiced, as well as a teacher. The most essential teacher's task is to be able to present the subject matter in accordance with the subjects in his care. The teacher is a professional job that requires special skills and expertise obtained from the results of the educational process [10]. Therefore, being a good teacher must master the material or subject matter that will be presented to students. Based on this description, the educational background of a teacher will greatly affect the professional ability and work motivation of the teacher.

The characteristics of professional teachers are if the teacher has the ability of high level of abstraction and high level commitment [11]. Commitment is broader than concern because commitment includes time and effort. The level of teacher commitment extends from the lowest to the highest. Teachers who have low commitment usually lack attention to students, as well as the time and energy spent to improve the quality of learning too little. Conversely, a teacher who has a high commitment is usually his attention to high students, so too much time is provided to improve education. Teachers who have a high level of abstract thinking, namely being able to formulate concepts, capture, identify, and solve various problems they face in carrying out their tasks.

Third, the experience or working period for a teacher in carrying out his duties is also one of intrinsic motivation. Many and long experiences in carrying out their duties as teachers will make a person more emotionally mature and critical thinking, so that in managing the learning process becomes better and more innovative. Based on the observations of the author in class during the learning process, shows that teachers who have a work period of six years to twenty years, have the ability, creative, innovative and skilled in carrying out their duties. Whereas teachers who have a tenure of more than twenty years are creative, innovative, and their skills begin to decline, rarely following the development of new knowledge, especially the development of materials. While teachers who have a working period of less than six years, they have high enthusiasm in carrying out their duties, but they are still learning and the emotional level is still not controlled in dealing with students during the learning process. Judging from the work experience, most of the teachers are in productive times and this greatly helps the learning process run smoothly and smoothly.

Fourth, hopes and ideals, a person who has hopes and ideals always wants to develop and wants to live better than what he has gained, and is a positive motivation in working or carrying out his tasks. If those hopes and aspirations arise sincerely without expecting something from someone, for example, want to pay attention to their boss or be promoted to a position, then that person will work diligently, full of enthusiasm and innovation, and he will be serious in carrying out his duties well even sometimes he becomes a role model for others in his work environment.
The results of the observations showed that the teachers in the school had hopes and aspirations to develop in a better direction in terms of improving the quality of their abilities and the positions they held. This can be seen from the opportunities given by school principals to take part in training, upgrading, workshops, seminars, or training for teachers. If it is not limited to the number that is chosen as a participant, most teachers all want to follow it.

The teachers carry out the tasks given to him well such as being a homeroom teacher, vice principal, managing libraries, pickets, head of the laboratory, student council supervisor, guiding students to make scientific works, guiding students of physics, physics, and mathematics and laboratory management. While improving the quality of professional skills, those who excel in completing their routine education will have the opportunity to attend training at home and abroad.

\section{2) Extrinsic motivation}

First, the leadership of the principal is the leader and manager of the school, as a leader and manager must be fair to his staff, paying equal attention to his staff, being friendly, giving assignments to the teacher must pay attention to the individual abilities of the teacher, and must be able to provide knowledge to teachers who succeed and perform well, and can provide guidance and reprimand to teachers who have not performed their duties well.

The results of observations and interviews with several teachers obtained an illustration that the principal in leading the school was always fair, both in the assignment of duties and responsibilities and in the distribution of welfare that was guided by the burden of the task carried out by the teacher. The relationship between the teachers and the principal runs well and is familiar. If there are teachers who are not good enough in carrying out their duties, the principal gives direction. Based on the results of these observations it can be seen that the principal has a large and humble soul, does not consider the position to be something to be proud of, but is a mandate that must be carried out, managed and accountable to both humans and Allah swt. The in perspective of Islam leadership is an activity of guiding, guiding, guiding, and demonstrating the path that Allah swt. The activity intends to develop the ability to work alone in the environment of people who are led in an effort to reach the pleasure of Allah swt in the world and in the hereafter [12].

The programs implemented so far by the principal along with the teachers are:

\section{a) Establishment of teacher professional capacity building.}

The professional capacity building for teachers is formed based on similar or cognate subject teachers gathered in the MGMP led by a chairman who is chosen by the MGMP members. With the existence of a teacher professional training capacity building, it has brought many benefits for improving the ability of teachers both in teaching and in classroom management.

b) Internal school coaching 
Internal coaching in schools is a routine effort or desire carried out by the Principal and school supervisors on teacher performance, so that in the end it is expected to improve teacher professionalism. Observations with the deputy headmaster and the documentation study contained several coaching materials for teachers, as follows: (a) delivery of information and explanation of the school's vision and mission as well as its achievement strategies, so that all teachers have the same attitudes, perceptions, and judgments regarding vision, mission and strategies for achieving it; (b) making mutual agreement in order to achieve the school's vision and mission as formulated; (c) preparing a work program or teaching program in a work meeting held at the beginning of the school year and the dissemination of new information relating to the learning process; (d) compile each task for vice principal, homeroom teacher, student advisor and others; (e) directing and coaching the vice principals in the implementation of teacher supervision in teaching as a follow up to delegation of authority/duties of the principal; (f) guidance on the implementation of K-13 for teachers both in preparing learning tools and implementing in the classroom; (g) an explanation of scholarships for outstanding students, underprivileged students; (h) explanation of the implementation of learning based on Islamic values; (i) explanation of the implementation of the National Final Examination; and (j) an explanation of the regular and bilingual class new student admission system. Determining the criteria and the selection system that is implemented and the available capacity.

In addition to the guidance patterns carried out by the school principal as described above, the principal also always seeks information and opportunities for teachers to continue their education to a higher level or upgrading or training in accordance with their field of work as well as seeking opportunities for various research programs that can be useful in developing the ability of teachers to carry out research.

Second, the work environment is an aspect that cannot be separated from a person's emotional. A desire to have satisfaction with the environment makes a person more creative, innovative and wants to promote and do good, more for his work environment. The working relationship among teachers, employees, principals, and all existing staff is well established, and the sense of social between others is very high. The work environment is very pleasant and harmonious relationships go well. This is one factor that strongly supports the learning process and is the capital and strength to carry out planned programs.

The factors that influence the work motivation of teachers in improving the quality of learning are two types, namely intrinsic motivation and extrinsic motivation. The fact was found that most teachers had sufficient professional skills in carrying out their daily tasks. This is supported by a relatively long teaching experience factor and teachers have attended many upgrading and training at the regional, national and international levels. In carrying out their duties the teacher is also relatively good even though there is still a tendency for the material to still be dominant in carrying out additional tasks besides teaching assignments.

\section{CONCLUSIONS AND SUGGESTIONS}

The results showed that: (1) motivation done by the teacher in carrying out his duties and responsibilities by: a) explaining the benefits and objectives of the material taught to students; b) teaching using various learning methods or strategies; c) provide opportunities for students to achieve success; and (d) giving awards or praise to students who perform tasks and perform well; (2) the factors that influence teachers work motivation are two types, namely intrinsic motivation and extrinsic motivation.

Many factors influence the work motivation of teachers in improving the quality of learning. This gives a recommendation that these factors can provide positive motivation in improving the task as well as possible.

\section{ACKNOWLEDGMENT}

Thanks to University of Medan, which has given me the opportunity to follow the S3 Study Program of Educational Management, and The Committee of AISTEEL-2018.

\section{REFERENCES}

[1] R. Cropanzano, J.C. Howes, A.A. Grandey, and P. Toth, "The Relationship of Organizational Politics and Support to Work Behaviors, Attitudes, and Stress," Journal of Organizational Behavior, vol. 18, 1997, pp. 159-180.

[2] M.L. Randall, R. Cropanzano, C.A. Bormann, and A. Birjulin, "Organizational Politics and Organizational Support as A Predictor of Work Attitudes, Job Performance, and Organizational Citizenship Behavior," Journal of Organizational Behavior, vol. 20, 1999, pp. 159174.

[3] D. W. Organ, "Organizational Citizenship Behaviour: It's Constuct Clean-up Time," Human Performance, vol. 10, 1997, pp. 85-97.

[4] J.P. Campbell, "Modeling the Performance Prediction Problem in Industrial and Organizational Psychology," in Handbook of Industrial and Organizational Psychology, vol. 1, M. D. Dunnette and L.M. Hough, Eds. Palo Alto, CA: Consulting Psychologists Press, 1990, pp. 687-732.

[5] F.C. Lunenburg and A.C. Ornstein, Educational Administration: Concepts and Practices, 3rd ed., Belmont, CA: Wadsworth/Thomson Learning, 2004, p. 111.

[6] Sugiyono, Metode Penelitian Kuantitatif, Kualitatif dan R\&D. Bandung: Alfabeta, 2010, p. 1.

[7] M.B. Miles and A.M. Huberman, Qualitative Data Analysis: An Expanded Sourcebook. California: Sage Publications, 1992, p. 12.

[8] Y.S. Lincoln and E.G. Guba, Naturalistic Inquiry. California: SAGE Publications, 1985, p. 289.

[9] Sardiman, Interaksi dan Motivasi Belajar. Jakarta: Rineka Cipta, 2000, p. 73.

[10] J.M. Cooper, Classroom Teaching Skills Ninth Edition. California: Wadsworth, Cengage Learning, 2011, p. 2.

[11] C.D. Glickman, Leadership for Learning: How to Help Teachers Succeed. Virginia: The Institute for Schools, Education, and Democracy, Inc., 2002, p. 89.

[12] A. Hakim, Kepemimpinan Berbasis Nilai-nilai Islami. Semarang: Unissula Press, 2013, p. 41. 